ISSN 2766-2624

\title{
Important Geophysical Comments for Nuclear Engineers and for the World Climate Democracy
}

Advances in Earth and Environmental Science

Rapid Communication

Florent Pirot

Independent Researcher, Valbonne, France

*Correspondence authors

Florent Pirot

Independent Researcher

Valbonne

France

Submitted : 1 Oct 2021 ; Published : 15 Oct 2021

\begin{abstract}
These are important comments that give examples for physicists, geophysics specialists, climate scientists and other scientific professions as they may attempt to organize systems "playing with fire » (trying to achieve more profit by going near the red line of the accident) and offer a fair suggestion for the modern-time "climate democracy " with a Popperian proposal on a climate standard.
\end{abstract}

The 1909 earthquake in Lambesc (Provence)

The event is suggested to be related to a group of people that had read books of Simonde de Sismondi and decided to coalesce in a community living off from stealing tourists of English origin in the French Riviera (or perhaps Jews) and gathered in a village of the hinterland where they gathered their hoarded objects and gold bought from the reselling far from the police. The geology (somehow magmatic from the lateral effect of the Fermionic condensate that carved the Rhône valley, see [1]) eventually triggers a earthquake destroying the stolen welfare.

There is an identical argument with an area with an attractive name for opportunists of an ideology also associated with Sismondi, Biobio in Chile, in 2010 ${ }^{1}$. Nazis escaped from the Third Reich had settled in South America and could have gathered there.

The periodic oscillation

It is important as a point of basic geophysics to remind the natural yearly geophysical oscillation that creates an underground flow of pressure accompanying it, with a latency ${ }^{2}$. The compression during the end-of-the-year period causes a reactivation of the underground and definitively explains the emergence of lights-in-the-trees traditions aimed at recreating the natural phenomenon, more powerful, associated with the slowdown, described for instance in $[2]^{3}$.

The slow down effect comes from the South and creates (systematically) a small heat up from tiny supplementary levels of underground fission in the (in particular) granitic soils. It explains the collective choices (as emerging effect, in the typical definition of Raymond Boudon) of picking precise dates for collective gatherings that correspond with the position on the globe as concerns this yearly momentum. The Thanksgiving tradition is the first. The St Nicolas (St Niklaas) comes soon after. The pendulation (paroxysm in the northernmost point of the cycle) is associated with Ste Lucie (maximum northern reach of the increased compression), followed by return - in which Stonehenge (gathering at the solstice) is more to the North than countries with a strong Christmas tradition, explaining the gathering three days later. The Beffana and the Reyes Magos in Italy and Spain follow. Similar phenomena appear in Japan and China with secular rituals (coming-of-age celebration) in Japan, and the Chinese New Year concluding.

\footnotetext{
${ }^{1}$ As organic farming reduces opportunities for mechanization and technology use in general, exactly fitting the pattern proposed by Sismondi in his books.

${ }^{2}$ This flow can be seen sometimes precisely. Indirectly with granite underground for instance in a pattern in the clouds.

${ }^{3} \mathrm{~A}$ case is given in Plobannalec (Finistère). A village in Auvergne actually bears the mark in its name : Fontclairant. It is located very close to a massive volcanic hill of Hawaïaan nature as everywhere in Auvergne and has a humid weather related to the granitic effect feeding the natural resurfacing of the pressure of the mountain next to it where the village has settled.
} 
The Georgian claim of having the « oldest Christmas tree custom in the world » is hence demonstrated in a simple way. Indeed Georgia, with its granitic underground and coniferous forests south of the Caucasus, is however in a place where that photon effect in granitic forests happens far from Christmas in the calendar, explaining the very early decision to reproduce the custom with ritual trees ${ }^{4}$.

It is obvious that the taking into account of that compression shift can allow the planner willing to increase the nuclear power in cores to reduce the activity precisely when the shift comes and to switch back to quasi criticality after. This remains a very risky activity, and the author is mostly against it. A number of nuclear accidents from the geophysical effect of supplementary neutrons from fission stimulated by human weight (industries overgrowing for various reasons) were already observed. The author would think of at least three cases. One very wellknown explosion explained by this phenomena is the AZF plant (actually phosphates - but the NORMs in phosphates were activated by some neutron coming from the underground in this humid environment (river next to the plant) causing a fission (one isolated u235 fission in NORMs) that lighted up from the underground the phosphate pile causing a large yellow fireball with limited radioactive fallout). The Seveso case in 1976 is a similar case. In both cases the excess military « heating » (overactivity with actual threats of nuclear war for what remains a terrorist attack - nuclear warfare being the opposite of the very asymmetrical tactics of Al Qaeda) has to be blamed - with the post- 9/11 works bringing too much geophysical pressure and causing an isolated blast. Likewise in Italy during the « years of lead».

It is also important to note (as concerns the semi-optimistic comments on regulation in Communist China post-1976 in [3]) that the issue of municipal and regional debt was left out from the manuscript as it was thought that in a Communist country money is anyway worthless and to be excluded from the serious debate. It was shown that the semi-optimist tone of that article was jumped upon by Communist decision makers who believed they could Actually Use a Virus to Quash Dissidents and Muster the Virus Without Failure because they believed the regime was in a certain way " anointed »... Historicism was denounced by Carl Menger, Ludwig von Mises and many others as a key folly of non-liberal thinkers who think they can predict the future based on past events. It is what happened in Wuhan - some CCP historicists took [3] and decided it was an actual Proof that their regime was Blessed and Bound to Succeed in the future while handling biowarfare agents in a civilian environment. Believing that governments are able to plan even renewable energy development in a sane way is not seeing the elimination of Falun Dafa ritualists by the CCP while it rolled out its own wind power plan (to take an extreme case), a wind power plan where component providers were not paid by the turbine manufacturers... at the end of a distribution scheme where provinces were ordering the energy development (see [4]). It is predictible that the Falun Dafa prayers with arms up in city squares were the sacrificial targets of the CCP throughout that process.

\section{A suggestion for a « human-controlled climatic standard for Earth »}

The 1991 temperatures, during the period between the 1st Gulf War and Hurricane Andrew are a very important and essential standard. The massive amounts of depleted uranium unleashed during Desert Storm have brought a storm, Hurricane Andrew, in an area close to the cities where people making money in the weapons industry (in Georgia for instance) and their government colleagues go to holidays, Florida. The U238 atoms liberated in the open atmosphere in a very hot climate after initial spinning by the tiny HEU tips' explosions kept on spinning (see [5], an essential reading here to understand) because of solar energy in the desert. The spin energy alone from the DU of the Gulf War creates a return of the spin with an identical pattern (the curved, slanted line of attack of the Western armies creating the overall spin movement that results eventually in a hurricane in the holiday areas of the weaponsmakers and their colleagues, because the use of depleted uranium was unneeded for justice).

The fact that a very precise military event creates a single localized hurricane leads to the proposal of using that period as climate standard; the usual fair subcriticality in nuclear power and carbon dioxide emissions to feed trees and vegetation growth and energy absorption in that growth (see also [6]) allow to offer that reasonable standard as policy target. The isolated 1976 drought in France ${ }^{5}$ is related to the initial set-up of the nuclear reactors together certainly with poor shielding (because that industry was nascent) together with the actual absence of plutonium extraction because the Helsinki conference had stabilized the relations with the USSR, and China did not appear as a threat yet (so no reactor shutdown for plutonium extraction, causing excess heat emissions). An opposite example is the brutal confinment in April 2021 in France causing a massive agricultural freeze and heavy losses from the associated quasi-stop of industrial activity ${ }^{6}$. Common sense recommends to pick the highest temperatures preliminary to the period where hurricanes have started to become a common trend and Hurricane Andrew stayed in

\footnotetext{
${ }^{4}$ The very recent opening of the Canarias volcano corresponds with the period of stability that allows some separation (period of least compression that allows the final breaching, of a magmatic pocket stimulated by relativistic neutrons (the same that broke the nuclear core of the Perle SNA) and by touristic overdevelopment on the hills altogether). Likewise it was observed a relative reduction of the flow of the Fagradalsfjall volcano in the precise summer solstice phase (for the compression is least important near the poles then) ; the volcano may be stimulated in December if no additional geothermy is installed before to take opportunity of the lost heat.
}

${ }^{5}$ Country where the last major waves of cold are remembered in the mid 1980s

${ }^{6}$ For the defense of the decisionmakers, it has to be underlined that it is mostly alcohol-related agriculture that suffered heavily. 
the memories as such. The 1970 hurricane in Bangladesh accompanies the periodic oscillation underlined earlier. Alpha emitters in the deep underwater (NORMs) somehow follow that periodic oscillation with underground current, driving with the electronegativity of storms a massive cloud. Hence 1970 cannot be taken as the climatic standard.

\section{References}

1. Pirot F (2021) Fermionic Condensation Explains the Formation of Subcontinents and Small Volcanic Islands around Them - General Geophysical Rules. International Journal of Physics. 9: 42-47.

2. Pirot F (2020) Alpha-Emitting Nanoparticulates and Their Various Physical Effects: More Case Studies in Laboratory Research and History, Applied Mathematics and Physics 8: 1-7.

3. Pirot F (2019) A Rule of Natural Disasters Coming to Rebalance Unjust Development and Irresponsibility-Laws of Physics Explain the Trope of "Divine Retribution" against the "Nouveaux Riches", International Journal of Physics 7: 135-140.

4. Pirot F (2021) The shuriken effect of fertile alpha emitters: a physical process behind findings of chemical toxicity of depleted uranium. International Journal of Nanoparticle Research 4: 15.

5. Pirot F (2019) Volcanic Tephras and Human Energy Losses Together: The Real Source of Climate Change, International Journal of Physics 7: 126-134.

Copyright: (C2021 Florent Pirot. This is an open-access article distributed under the terms of the Creative Commons Attribution License, which permits unrestricted use, distribution, and reproduction in anymedium, provided the original author and source are credited. 